Table 1. Age of menarche in diabetic and non-diabetic women

\begin{tabular}{lcccc}
\hline $\begin{array}{l}\text { Age at } \\
\text { menarche } \\
\text { (years) }\end{array}$ & \multicolumn{2}{l}{$\begin{array}{l}\text { Non-diabetic } \\
\text { subjects }\end{array}$} & \multicolumn{3}{l}{ Diabetic patients } \\
Number & $(\%)$ & & Number & $(\%)$ \\
\hline 9 & - & - & 3 & 0.3 \\
10 & 11 & 0.6 & 15 & 1.5 \\
11 & 142 & 7.3 & 75 & 7.5 \\
12 & 423 & 21.7 & 165 & 16.7 \\
13 & 725 & 37.2 & 195 & 19.8 \\
14 & 534 & 27.4 & 249 & 25.2 \\
15 & 63 & 3.2 & 99 & 10.0 \\
16 & 21 & 1.1 & 96 & 9.7 \\
17 & 8 & 0.4 & 48 & 4.9 \\
18 & 10 & 0.5 & 27 & 2.7 \\
19 & 8 & 0.4 & 12 & 1.2 \\
20 & 6 & 0.3 & 1 & 0.1 \\
21 & - & - & 2 & 0.2 \\
\hline Total & 1952 & & 987 & \\
\hline
\end{tabular}

\section{References}

1. Bailey CJ, Ahmed-Sorour H (1980) Role of ovarian hormones in the long-term control of glucose homeostasis. Effects on insulin secretion. Diabetologia 19: 475-481

2. Kalkhoff RK (1975) Effects of oral contraceptive agents on carbohydrate metabolism. J Steroid Biochem 6: 949-956

3. Houssay BA (1951) Action of sex hormones on experimental diabetes. Br Med J II: 505-510

4. Ionescu-Tirgoviste C, Pop E, Burdescu N, Bolcas I, Ionescu C, Popa E, Negoescu E, Santu E, Lichiardopol R (1980) Delayed menarche as indicator of a prediabetic state. $1^{\text {st }}$ Roumanian Congress of Nutrition and Metabolic Diseases, Bucharest 18-20 September 1980.

5. Hanssen KF, Torjesen PA (1977) Increased prolactin in diabetic ketoacidosis: correlation between serum sodium and serum prolactin concentrations. Acta Endocrinol (Kbh) 85: 372-378

6. Landgraf R, Landgraf-Leurs MMC, Weissmann A, Hörl R, von Werder K, Scriba FC (1977) Prolactin: a diabetogenic hormone. Diabetologia 13: 99-104

7. Tournaire J, Pallo D, Pousset G, Bizollon C, Bachelot J (1974) Diminuation de la tolérance glucidique et hyperinsulinisme dans l'adenome à prolactin. Nouv Presse Méd 3: 1705-1707

C. Ionescu-Tirgoviste, E. Popa and D. Cheta

Clinic of Nutrition and Metabolic Diseases

I. Movila 5-7,

Bucharest 2, Romania

\title{
Cord Blood C-Peptide: Glucose Ratio - a Good Indicator of B Cell Function in Infants of Diabetic Mothers
}

Dear Sir,

We would like to supplement recent observations [1] on the B cell function in infants of diabetic mothers. We too, have measured cord blood C-peptide and glucose, the former after initial precipitation of insulin antibodies with polyethylene glycol [2], to compare the true $B$ cell response of a group of 44 infants of insulinrequiring diabetic mothers with 32 infants of non-diabetic mothers. We divided the infants of diabetic mothers into two groups dependent upon the quality of their mothers' blood glucose control and their glycosylated haemoglobin concentration [3] and not on the basis of the presence or absence of insulin antibodies. The results are presented below as group means \pm one standard deviation.

We found the mean cord blood glucose of our normal babies $(3.9 \pm 1.0 \mathrm{mmol} / 1)$ was lower than that of infants of diabetic mothers $(4.7 \pm 3.6 \mathrm{mmol} / \mathrm{l})$. The $\mathrm{C}$-peptide values were: normal infants $0.18 \pm 0.1 \mathrm{nmol} / 1$ and infants of diabetics $0.46 \pm 0.44 \mathrm{nmol} / \mathrm{l}$. Comparison of the results using a variance ratio test showed that the cord blood glucose and C-peptide concentrations were significantly different. When the diabetic group was re-examined after subdivision on the basis of diabetic control the mean cord blood $\mathrm{C}$ peptide of infants of well controlled diabetic mothers was $0.28 \pm$ $0.3 \mathrm{nmol} / 1 \mathrm{compared}$ with a mean of $0.56 \pm 0.5 \mathrm{nmol} / 1$ for infants of poorly controlled mothers, a difference which is highly significant by the variance ratio test.

We have always believed that the cord blood C-peptide: glucose ratio at delivery avoids the problems of comparing B cell function of groups with different glucose values. We found the mean of the C-peptide:glucose ratio for infants of normal mothers was $0.049 \pm 0.029$ whilst infants of diabetic mothers as a group had a higher mean at $0.110 \pm 0.09$. When the ratios of infants of well and poorly controlled diabetic mothers were compared, infants of well controlled mothers had a significantly lower mean value of $0.06 \pm 0.06$ compared with these of poorly controlled mothers $0.13 \pm 0.09(\mathrm{p}<0.005)$. The value of this ratio is that it identifies those infants with inappropriate $B$ cell response more clearly. Seventeen of our infants of diabetic mothers had a cord blood C-peptide above the observed upper limit of the range for normal infants $(0.4 \mathrm{nmol} / \mathrm{l})$ but two were shown to have a normal C-peptide: glucose ratio indicating a normal insulin responsiveness per unit of glucose; both mothers of these two infants had transient hyperglycaemia at delivery but otherwise had good diabetic control throughout the final trimester. However, the ratio was high in the other 15 infants and was consistent with poor maternal control during pregnancy.

The C-peptide:glucose ratio in cord blood therefore provides a better measure of $\mathrm{B}$ cell secretory status of the newborn of diabetics than C-peptide alone and provides a useful tool for retrospective evaluation of the diabetic control of the mothers.

Yours sincerely

B. J. Burke, C. J. Owens and C. A. Pennock

\section{References}

1. Heding LG, Persson B, Stangenberg M (1980) B cell function in newborn infants of diabetic mothers. Diabetologia 19: 427-432

2. Kuzuya H, Blix PM, Horwitz DL, Steiner DF, Rubenstein AH (1977) Determination of free and total insulin and C-peptide in insulin treated diabetics. Diabetes 26: 22-29

3. Burke BJ, Dixon G, Savage PE, Owens CJ, Pennock CA, Sherriff RJ (1981) Glycosylated haemoglobin in the assessment of diabetic control in pregnancy. J Obstet Gynaecol 1: 153-156

B. J. Burke

Bristol Maternity Hospital

Bristol, England 